Benedykt Opałka

\title{
PLANOWANIE I OCENA PROJEKTÓW INWESTYCYJNYCH JEDNOSTEK SAMORZĄDU TERYTORIALNEGO Z WYKORZYSTANIEM METOD BUDŻETOWANIA ZADANIOWEGO
}

\section{Wprowadzenie}

Polityka inwestycyjna prowadzona przez jednostki samorządu terytorialnego oraz inne podmioty sektora publicznego oznacza podejmowanie decyzji na różnych szczeblach władzy, których nadrzędny cel można określić jako dążenie do poprawy sytuacji w danej dziedzinie, w odniesieniu przede wszystkim do okresów przyszłych. Należy również podkreślić, że polityka inwestycyjna samorządu terytorialnego oddziałuje wielopłaszczyznowo na ogólny poziom życia mieszkańców danej jednostki terytorialnej. Podstawę do takich wniosków stwarza ocena reprezentatywnych mierników poziomu życia mieszkańców. Można przyjąć, że wzrost poziomu życia mieszkańców jest mierzalny w badaniach ekonomiczno-społecznych w wysokościach wydatków bieżących oraz ich dynamice charakteryzującej tempo przemian w tym obszarze, jak również zakresie świadczonych usług użyteczności publicznej, ich dostępności, poziomie cen i opłat taryfowych. Skutki decyzji dotyczących wydatkowania środków finansowych na dany projekt lub portfel projektów inwestycyjnych mogą mieć szeroki zasięg oddziaływania, zwłaszcza gdy przy słabo rozpoznanej sytuacji bieżącej budżetu oraz źle opracowanych prognozach kształtowania się dochodów budżetu w przyszłości może dojść do konieczności ograniczania wydatków bieżących.

Metodyka budżetowania zadaniowego jest dość obszernie scharakteryzowana w literaturze przedmiotu oraz upowszechniona i stosowana w zróżnicowanych jednostkach sektora publicznego w wielu krajach, m.in. w Unii Europejskiej. W Polsce próby stosowania budżetu zadaniowego $\mathrm{w}$ jednostkach samorządu terytorialnego podejmowane były już w połowie lat 90 . XX w. Intensyfikacja prac na poziomie 
rządowym nad stworzeniem ram prawnych i rozwoju metod budżetowania w układzie zadaniowym, następująca od roku 2008, pozwala zaobserwować wymierne efekty w postaci nowych rozwiązań legislacyjnych (m.in. znowelizowana ustawa o finansach publicznych) oraz sukcesywnego stosowania układu zadaniowego w odniesieniu do budżetu państwa. Należy oczekiwać, że wpływa to również na rozprzestrzenianie się wypracowanych rozwiązań na poziom budżetów jednostek samorządu terytorialnego.

Obecnie jednostki samorządu terytorialnego sporządzają budżet zgodnie z zasadą jedności materialnej, która oznacza m.in. brak powiązania finansowania wydatków z poszczególnymi źródłami dochodów. Powyższy sposób planowania i realizacji budżetu bezpośrednio nie pozwala jednak na pełną analizę zdolności inwestycyjnej lub zdolności spłaty zadłużenia danej jednostki. Na potrzeby analiz i ocen, szczególnie o charakterze długookresowym, konieczne jest dokonanie transformacji budżetu jednostek samorządu terytorialnego sporządzanego według tradycyjnej metody, na budżet zadaniowy, umożliwiający badanie faktycznych przepływów pieniężnych.

Obserwowane w ostatnich latach zjawiska kryzysu gospodarczego wpływaja na wielkość poszczególnych grup dochodów budżetowych jednostek samorządu terytorialnego, wzrost bezrobocia czy nasilające się negatywne zjawiska demograficzne. W sektorze publicznym należy zatem wskazać na wzrastające potrzeby wnikliwej weryfikacji planów budżetowych oraz prognozowania nadwyżki wolnych środków budżetu operacyjnego w kontekście zdolności do finansowania nowych projektów inwestycyjnych w perspektywie wieloletniej. Tego rodzaju podejście w warunkach realizacji inwestycji publicznych w Polsce skłania do podjęcia próby oceny metodyki budżetowania zadaniowego jako czynnika wpływającego na zdolności inwestycyjne oraz zakres wykorzystania analizy wskaźnikowej na potrzeby planowania i oceny projektów inwestycyjnych w jednostkach samorządu terytorialnego.

Celem przedłożonego badania jest analiza i ocena możliwości wykorzystania metod budżetowania zadaniowego w zakresie planowania, finansowania i badania efektywności projektów inwestycyjnych jednostek samorządu terytorialnego w Polsce. Jako tezę główną autor przyjął, że wzrost skuteczności i racjonalności planowania projektów inwestycyjnych oraz badanie ich efektów ekonomicznych mogą być osiągane poprzez zastosowanie układu budżetu, który pozwala ocenić zdolności inwestycyjne jednostek samorządu terytorialnego oraz wykorzystać elementy analizy wskaźnikowej w zakresie poszczególnych zadań podejmowanych przez powyższe jednostki w perspektywie jednorocznej oraz wieloletniej. 


\section{Polityka inwestycyjna jednostek samorządu terytorialnego w Polsce}

Proces planowania strategicznego, rozumiany jako świadome, systematyczne i ukierunkowane na przyszłość przygotowywanie i podejmowanie przez władze samorządowe decyzji, obejmuje zagadnienia poziomu rozwoju gminy w przyszłości, zaspokojenia potrzeb społeczności lokalnej oraz koordynacji i integracji podejmowanych działań realizacyjnych na rzecz przyjętych ustaleń planistycznych, z uwzględnieniem uwarunkowań zewnętrznych i wewnętrznych ${ }^{1}$. Planowanie inwestycji publicznych wiąże się bezpośrednio z konkretnymi działaniami podmiotów sektora publicznego i powinno być poprzedzone badaniami w zakresie rzeczywistych potrzeb określonych grup społecznych. Rozpoznanie potrzeb może prowadzić w dalszej kolejności do formułowania przedsięwzięć inwestycyjnych, dla których ustala się określoną metodykę finansowania. Jedną z powszechnie stosowanych w praktyce metod wyłaniania przyszłych potrzeb, a następnie formułowania projektów inwestycyjnych jest wieloletnie planowanie rozwoju społeczno-gospodarczego. Pozwala to wykorzystać istotną cechę procesu planowania strategicznego, jaką jest możliwość badania wzajemnych związków występujących wewnątrz jednostek osadniczych czy jednostek podziału administracyjnego oraz łączne ujmowanie wszystkich problemów lokalnych o charakterze społecznym, gospodarczym, przestrzennym i środowiskowo-ekologicznym. Kompleksowe podejście do spraw lokalnych prowadzi do rozwiązywania przyszłych problemów rozwojowych w ich wzajemnych związkach, opierając się na lokalnych możliwościach i z uwzględnieniem występujących ograniczeń.

Metodyka zarządzania strategicznego wspomaga procesy porównywania i szeregowania problemów rozwoju infrastruktury komunalnej w kategoriach wartości ekonomicznych, przestrzennych oraz społecznych w sytuacji ograniczonych zasobów finansowych, jakie mogą być przeznaczone na realizację inwestycji. Zgodnie z zapisem art. 44 ust. 3 ustawy z dnia 27 sierpnia 2009 r. o finansach publicznych „wydatki publiczne powinny być dokonywane w sposób celowy i oszczędny, z zachowaniem zasady uzyskiwania najlepszych efektów z danych nakładów, umożliwiający terminową realizację zadań publicznych oraz w wysokości i terminach wynikających z wcześniej zaciągniętych zobowiązań”’. Poprawa efektywności publicznych inwestycji infrastrukturalnych, służąca wykonaniu wyżej wymienionego przepisu, wydaje się możliwa dzięki procedurom i instrumentom merytorycznym, kształtującym

1 M. Świetlik, M. Ziółkowski, System planowania strategicznego rozwoju gminy, na prawach rękopisu, Warszawa 1999, s. 7.

2 Ustawa z dnia 27 sierpnia 2009 r. o finansach publicznych, DzU nr 157, poz. 1240 z późn. zm. 
m.in. sformalizowane mechanizmy rozwoju infrastruktury komunalnej i służącym zachowaniu ciągłości realizacji zadań samorządu terytorialnego w długim okresie. Sformułowane w wyniku powyższego procesu cele strategiczne gminy stają się następnie priorytetami wskazującymi hierarchię oceny projektów inwestycyjnych, warunkującymi ich uszeregowanie w formie inwestycyjnych planów średniookresowych, a następnie realizację. Wraz z odniesieniem powyższych planów do możliwości finansowych gminy, określonych poprzez sporządzenie wieloletniego planu finansowego, wszystkie przedstawione działania tworzą możliwy do zastosowania w praktyce system zarządzania inwestycjami w gminie, zachowujący zgodność z oczekiwaniami społeczności lokalnej w zakresie zaspokajania zbiorowych potrzeb społecznych. Cele strategiczne mogą zatem stanowić podstawę do poszukiwania rozwiązań organizacyjnych służących wdrażaniu ich szczegółowych zapisów i w konsekwencji - stwarzania możliwości ich osiągania.

Zgodnie z zakresem posiadanych uprawnień o charakterze administracyjnym władze samorządowe mają możliwość oddziaływania na poszczególne rodzaje zasobów danej jednostki terytorialnej. Przykładowo, na mocy przepisów ustawy o samorządzie gminnym władze samorządowe w Polsce, działając w imieniu społeczności lokalnej poprzez decyzje administracyjne i akty prawa lokalnego, mogą wpływać pośrednio lub bezpośrednio na zmiany w sferze gospodarczej, społecznej i ekologiczno-przestrzennej na obszarze całej gminy. Informacje o stanie poszczególnych zasobów gminy mogą być uzyskane poprzez kompleksowe analizy o charakterze ciągłym, co pozwalałoby na zdobycie zasobów wiedzy niezbędnej do oceny stopnia zaspokojenia potrzeb społecznych i planowania interwencji w tych sferach lokalnej gospodarki, gdzie występują najważniejsze problemy. Jak wspomniano, rolą władz samorządowych wyłonionych w procesie demokracji lokalnej powinno być dążenie do rozpoznania zbiorowych potrzeb społecznych i stworzenia instrumentów zaspokajania tychże potrzeb.

Zdaniem T. Dziurbejki należy tu koncentrować działania na badaniu powiązań pomiędzy efektami planowania oraz maksymalizowaniem skuteczności pozyskiwania środków na inwestycje ${ }^{3}$. Stąd też kryteria oceny projektów przedkładanych jako propozycje do sfinansowania w ramach planów rozwojowych powinny w znacznym stopniu uwzględniać identyfikowanie projektów najlepszych pod względem osiągania ustalonych celów rozwoju lokalnego czy szczegółowego działania oraz najlepiej przygotowanych i gwarantujących osiągnięcie założonych rezultatów po najniższym koszcie. W kontekście szczególnie istotnym dla Polski, tj. pozyskiwania dofinansowania

3 T. Dziurbejko, Planowanie rozwoju gminy jako instrument pozyskiwania funduszy pomocowych Unii Europejskiej, Difin, Warszawa 2006, s. 185. 
z funduszy unijnych, projekt jako podstawowa jednostka objęta pomocą Unii Europejskiej uznawany jest za punkt wyjścia dla rozwoju metod analizy i planowania rozwoju na poziomie lokalnym, regionalnym i krajowym, jak również w ogólnym procesie programowania funduszy strukturalnych Unii Europejskiej. Dlatego też w zakresie polityki spójności realizowanej w ramach całej UE można mówić o wysokim stopniu skoordynowania cyklu programowania rozwoju lokalnego lub regionalnego z cyklem życia projektu ${ }^{4}$. Na tle rozwiązań przyjętych w innych krajach UE także w Polsce zauważalna jest potrzeba intensyfikacji działań na rzecz wzmocnienia funkcji wieloletniego planowania obejmującego wydatki inwestycyjne w instytucjach sektora publicznego jako instrumentu zarządzania. Istotnym argumentem uzasadniającym powyższą perspektywę czasową jest w tym przypadku dostosowanie się do systemu planowania i wykorzystania funduszy strukturalnych i Funduszu Spójności UE. Propozycja taka wydaje się korzystna również z punktu widzenia synchronizacji programowania krajowych środków publicznych jako wkładu własnego w ramach inwestycji współfinansowanych ze środków UE.

\section{Przesłanki wdrażania budżetu zadaniowego w zakresie inwestycji publicznych}

Poszukiwanie możliwości zastosowania budżetu jako narzędzia zarządzania stało się przedmiotem dynamicznie rozwijających się badań w Stanach Zjednoczonych w latach 50. XX w. Procedury i techniki budżetowania, stosowane początkowo jedynie do zarządzania środkami publicznymi na poziomie makroekonomicznym, poddane zostały procesom rozwojowym przez sektor przedsiębiorstw komercyjnych ${ }^{5}$. Współcześnie w praktyce finansów podmiotów sektora publicznego powszechnie stosowane są trzy metody budżetowania ${ }^{6}$ :

- budżetowanie przyrostowe (określane również jako historyczne),

- budżetowanie programowe,

- budżetowanie od zera.

W Polsce podstawową metodą budżetowania w sektorze publicznym jest budżet tradycyjny (przyrostowy), który jest najprostszy do zastosowania, ale jednocześnie

\footnotetext{
4 Ibidem, s. 186.

5 G. Bucior, B. Zackiewicz, Wykorzystanie budżetu w zarządzaniu jednostkami samorządu terytorialnego, w: Budżetowanie działalności jednostek gospodarczych - teoria i praktyka, pr.zb. pod red. W. Krawczyka, KZF WZ AGH, Kraków 2003, s. 49.

6 G. Kozuń-Cieślak, Budżetowanie w jednostkach samorządu terytorialnego - reorientacja $z$ administrowania na zarzadzanie, „Finanse Komunalne” 2010, nr 9.
} 
najmniej stymulujący podnoszenie efektywności. Istotą tej metody budżetowania, zgodnie ze stosowaną też nazwą metody historycznej, jest ustalanie budżetu na kolejny rok budżetowy na podstawie wykonania budżetu z poprzedniego okresu. Budżet może być ewentualnie modyfikowany adekwatnie do planowanych zmian rozmiarów aktywności danej jednostki i oczekiwanego poziomu inflacji. Jak wskazuje G. Kozuń-Cieślak, w ramach powyższej metody rozróżniane są ponadto dwie metody szczegółowe. Pierwsza z nich, określana jako line-item budgeting, umożliwia tworzenie budżetu w układzie tradycyjnym, który jest opracowywany w formie tablic ujmujących pozycje dochodów i wydatków zgodnie z klasyfikacją budżetową. Druga z metod szczegółowych, funkcjonująca pod nazwą activity based budgeting, stanowi rozszerzoną wersją budżetu tradycyjnego, polegającą na wyodrębnieniu realizowanych przez dany podmiot działań, a następnie przyporządkowaniu im odpowiednich środków finansowych ${ }^{7}$.

W Polsce główne zasady planowania i dysponowania środkami publicznymi określa ustawa $\mathrm{z}$ dnia 27 sierpnia 2009 r. o finansach publicznych. Pomimo wcześniejszych zmian przepisów ustawy o finansach publicznych do końca 2009 r. utrzymywane było jednak istotne ograniczenie dla realizacji inwestycji finansowanych ze środków publicznych w postaci braku jednoznacznie wskazanej formalnej podstawy do złożenia deklaracji przez jednostkę samorządu terytorialnego (występującą jako wnioskodawca) o zapewnieniu wkładu środków własnych na okres dłuższy niż bieżący rok budżetowy. Roczne budżetowanie, nawet gdy w formie załącznika do ustawy wyodrębnione były inwestycje i programy wieloletnie, oznaczało w praktyce brak gwarancji zapewnienia ciągłości wstępnie zakładanych strumieni finansowych na programy i inwestycje wieloletnie.

Jednym z elementów racjonalizacji zarządzania finansami publicznymi jest wdrażanie metod budżetowania opartych na jednoznacznym podziale kompetencji i zasadach odpowiedzialności oraz przejrzystości i jawności podejmowanych decyzji. Należy jednak podkreślić, że z uwagi na złożoność i specyfikę działalności sektora publicznego proces budżetowania w tym sektorze jest trudny do zrealizowania, gdyż wymaga uwzględniania zarówno ekonomicznego, jak i społecznego wymiaru podejmowanych decyzji. Koncepcje programowego systemu organizacji działalności podmiotów sektora publicznego, $\mathrm{z}$ powodzeniem stosowane w gospodarkach wysoko rozwiniętych, w Polsce znalazły wyraz w tzw. budżecie zadaniowym.

Budżet zadaniowy należy określić jako typ budżetu rezultatów, który posiada wszystkie zalety charakterystyczne dla tej metody budżetowania. Istotą budżetu zadaniowego jest zarządzanie działalnością jednostki samorządu terytorialnego poprzez

7 Ibidem. 
ujęcie tej działalności w zadania. Jest to plan finansowy danej jednostki, przygotowany w taki sposób, że zanim wydatki zostaną zapisane w tradycyjnej klasyfikacji budżetowej (dział - rozdział - paragraf) przygotowywane są w postaci zadań budżetowych, obejmujących zarówno składniki działalności bieżącej, jak i działania inwestycyjne. Środki alokowane są tak, aby jak najlepiej służyły osiągnięciu zamierzonych efektów ${ }^{8}$. Istota procesu badania ich wydatkowania dotyczy zatem w mniejszym stopniu obszaru formalnego, wynikającego z klasyfikacji budżetowej, natomiast ważniejsza staje się ocena, czy w wyniku wydatków osiągnięto zamierzony rezultat. Poprzez podział działalności podmiotu na programy ukierunkowane na osiąganie zróżnicowanych celów dystrybucja posiadanych funduszy dokonywana jest według programów, a nie w formie budżetów poszczególnych jednostek organizacyjnych. W realizacji określonego programu może również brać udział kilka jednostek organizacyjnych tworzących strukturę podmiotu.

Jedną z powszechnie stosowanych metod szczegółowych budżetowania zadaniowego jest metoda określana jako performance based budgeting. Powyższy typ budżetu wskazuje cele planowanych wydatków, koszty realizacji programów proponowanych w ramach wyznaczonych celów, rezultaty podjętych działań oraz ich pomiar. Szczególny nacisk położony jest na pełny pomiar kosztów, wycenę wkładu pracy i koszty jednostkowe9.

Wśród korzyści możliwych do osiągnięcia w wyniku implementacji budżetu zadaniowego należy w szczególności wyróżnić:

- usprawnienie zarządzania finansami, wykraczające poza zakres ewidencji księgowej oraz sprawozdawczości i obejmujące bardziej funkcjonalny wymiar, tj. zarządzanie zadaniami (projektami) reprezentującymi jednocześnie aspekty rzeczowe i finansowe, wraz z pomiarem efektów działania administracji publicznej,

- wygenerowanie kryteriów alokacji środków i sposobu planowania budżetu, które zachowują wysoki poziom obiektywności ocen sporządzanych dla każdego projektu,

- rozszerzenie zakresu wykorzystania mechanizmów rynkowych, zastosowanie kryteriów ekonomicznych w procesie rozdysponowania środków z budżetu, jak też w ocenie oferowanych usług pod względem osiągania założonych standardów jakości (stwarzając jednocześnie podstawy do wyboru korzystniejszych ofert czy metod świadczenia usług oraz możliwość porównania kosztów świadczenia wybranych usług z cenami rynkowymi w warunkach sektora prywatnego $)^{10}$.

\footnotetext{
8 Ibidem.

9 Ibidem.

${ }^{10}$ Szerzej zob. J. Filas, M. Piszczek, I. Stobnicka, Budżet zadaniowy - narzędzia i procedury, Agencja Rozwoju Komunalnego, Kraków 1999, s. 31-32.
} 
Wdrożenie budżetu zadaniowego uznane jest za bardzo istotne przedsięwzięcie w zakresie reformy finansów publicznych oraz administracji publicznej w Polsce. Ma ono wspierać proces uzyskania przez Polskę poziomu konkurencyjności, właściwego dla krajów rozwiniętych, zarówno w wymiarze społecznym, jak i gospodarczym, ułatwiać spełnienie kryteriów konwergencji oraz implementację strategii lizbońskiej. Reforma polegająca na wdrożeniu budżetu zadaniowego, jako systemu nowoczesnego zarządzania wydatkami publicznymi, jest projektem wieloletnim. Prace nad metodyką i pilotażami prowadzone są od I kwartału 2006 r. przez Kancelarię Prezesa Rady Ministrów we współpracy z ministrem finansów. Do chwili obecnej Polska poczyniła ogromny postęp na tej drodze - od marca 2006 r. podjęto bardzo wiele istotnych decyzji organizacyjnych i merytorycznych w zakresie wdrażania budżetu zadaniowego. W $2008 \mathrm{r}$. budżetem zadaniowym objęto tylko część wydatków budżetu państwa (44\% wykazanych w projekcie ustawy budżetowej na $2008 \mathrm{r}$. $)^{11}$. W $2012 \mathrm{r}$. budżetem zadaniowym mają zostać objęte wszystkie jednostki sektora finansów publicznych, zaś szczegółowe regulacje dotyczące wdrażania budżetów w układzie zadaniowym wprowadza nowa ustawa o finansach publicznych z 27 sierpnia 2009 r. ${ }^{12}$

\section{Uwarunkowania organizacyjno-prawne zastosowania budżetu zadaniowego w jednostkach samorządu terytorialnego}

Wypełnianie zadań własnych jest obowiązkiem ustawowym jednostek samorządu terytorialnego. Niezależnie od tego, czy w danym przypadku działalność jest prowadzona przez daną jednostkę, czy też została powierzona innym podmiotom, władze samorządowe są odpowiedzialne za świadczenie usług publicznych i zaspokajanie zbiorowych potrzeb wspólnoty samorządowej. Prowadzi to w konsekwencji do potrzeby wyłaniania kluczowych problemów rozwojowych, identyfikowania barier oraz dokonywania trudnej hierarchizacji działań w czasie. Obserwacja dotychczasowych doświadczeń jednostek samorządu terytorialnego wskazuje na niewykorzystanie wszystkich możliwości, w ramach posiadanych zasobów, przez władze publiczne odpowiedzialne za rozwiązywanie problemów rozwojowych. $\mathrm{Z}$ doświadczeń tych wynika również, że stosowane metody realizacji inwestycji nie zawsze okazywały się

\footnotetext{
${ }^{11}$ Raport. Budżet zadaniowy, t. 1: Budżet zadaniowy na rok 2008, Kancelaria Prezesa Rady Ministrów, Departament Budżetu Zadaniowego, Warszawa 2007, s. 19.

${ }^{12}$ G. Kozuń-Cieślak, op.cit.
} 
skuteczne, prowadząc do licznych dysproporcji przestrzennych w poziomie wyposażenia jednostek osadniczych oraz do nadmiernego przerostu kosztów w stosunku do pierwotnych założeń kosztorysowych czy rozwiązań o charakterze alternatywnym.

Zgodnie z zapisem art. 52 ustawy o samorządzie gminnym oraz art. 233 ustawy z dnia 27 sierpnia 2009 r. o finansach publicznych projekt budżetu gminy jest przygotowywany przez organ wykonawczy gminy i po zatwierdzeniu przez organ uchwałodawczy gminy staje się obowiązującym aktem prawa lokalnego. Definicja budżetu inwestycyjnego wynika również z ustawy z dnia 27 sierpnia 2009 r. o finansach publicznych, w której zapisy art. 236 ust. 1 i 4 wskazują, że w budżecie jednostki samorządu terytorialnego wyróżnia się wydatki majątkowe, w których zakres wchodzą inwestycje i zakupy inwestycyjne, zakup i objęcie akcji oraz wniesienie wkładów do spółek prawa handlowego.

Instrumenty gospodarki budżetowej, wprowadzone na mocy ustawy z dnia 27 sierpnia 2009 r. o finansach publicznych, istotnie wpłynęły na planowanie wydatków budżetowych. W ustawie zdefiniowano bowiem Wieloletni Plan Finansowy Państwa, wieloletnią prognozę finansową jednostek samorządu terytorialnego oraz przedstawiono nowe ujęcie tzw. budżetu zadaniowego, który tym razem określono mianem „układu zadaniowego” oraz „skonsolidowanego planu wydatków”13. Według zapisu art. 103 wyżej wymienionej ustawy Wieloletni Plan Finansowy Państwa jest zdefiniowany jako plan dochodów i wydatków oraz przychodów i rozchodów budżetu państwa. Założenia dotyczące funkcji i struktury planu przyjęte w ustawie o finansach publicznych wskazują, że jest on sporządzany na cztery lata budżetowe w układzie obejmującym funkcje państwa, wraz z określonym zbiorem celów i wskaźników dotyczących stopnia wykonania danej funkcji, przy uwzględnieniu celów średniookresowej strategii rozwoju kraju oraz kierunków polityki społeczno-gospodarczej Rady Ministrów. W planie powinny być ponadto zawarte, w podziale na poszczególne lata budżetowe, prognozy podstawowych wielkości makroekonomicznych i określonych wskaźników budżetowych oraz kierunki polityki fiskalnej państwa.

Cele i konstrukcja wieloletniej prognozy finansowej jednostek samorządu terytorialnego wzorowane są na Wieloletnim Planie Finansowym Państwa. W art. 226 ww. ustawy określono, że wieloletnia prognoza finansowa powinna być realistyczna i określać dla każdego roku objętego prognozą m.in. takie parametry, jak: wielkości dochodów i wydatków budżetu - bieżących oraz majątkowych, wynik budżetu jednostki samorządu terytorialnego wraz dyspozycjami dotyczącymi nadwyżki lub

${ }^{13}$ C. Kosikowski, Reforma finansów w Polsce w świetle nowej ustawy o finansach publicznych, „Państwo i Prawo" 2009, nr 1, s. 5. 
sfinansowania deficytu, wielkości przychodów i rozchodów budżetu jednostki samorządu terytorialnego, kwotę długu jednostki samorządu terytorialnego (z uwzględnieniem długu zaciągniętego oraz planowanego do zaciągnięcia) oraz wskazanie sposobu sfinansowania spłaty długu. W ocenie sformułowanej przez C. Kosikowskiego nowe przepisy nie powodują zwiększenia w istotnym stopniu trwałości obowiązywania zapisów wieloletniej prognozy finansowej w stosunku do stosowanych poprzednio wieloletnich programów inwestycyjnych. Do wniosku takiego skłania analiza zapisów art. 230 i art. 231 ustawy z dnia 27 sierpnia 2009 r. o finansach publicznych, gdzie wskazano, że organowi stanowiącemu jednostki samorządu terytorialnego przysługuje uprawnienie w zakresie uchylenia obowiązującej uchwały $\mathrm{w}$ sprawie wieloletniej prognozy finansowej, jedynie pod warunkiem podjęcia nowej uchwały $\mathrm{w}$ tej sprawie, natomiast zmiana kwot wydatków na realizację przedsięwzięć może nastąpić w wyniku podjęcia uchwały organu stanowiącego jednostki, zmieniającej zakres wykonywania lub wstrzymującej wykonywanie danego przedsięwzięcia ${ }^{14}$.

Proces wieloletniego planowania inwestycji obejmuje usystematyzowanie metod przygotowania i wdrażania zadań inwestycyjnych i rozdysponowanie środków głównie na te, które przyczynią się zarówno do pobudzenia lokalnej gospodarki, jak i rozwoju w sferze społecznej, z uwzględnieniem zagadnień ochrony środowiska. Istotą budżetu zadaniowego jest natomiast zarządzanie całością działalności jednostki samorządu terytorialnego poprzez ujęcie tej działalności w zadania. Dotyczy to wykonywanych przez daną jednostkę kompetencji ustawowych, obowiązków zleconych przez administrację rządową i innych wynikających z woli samorządu, określanych na podstawie priorytetów zawartych w programie gospodarczym oraz potrzeb mieszkańców. Poprzez układ zadaniowy budżet staje się czytelny i przejrzysty, zrozumiały dla jego wykonawców - zarządu jednostki samorządu terytorialnego oraz pracowników poszczególnych komórek organizacyjnych, wzmacniając motywację do szerszego udziału w tworzeniu budżetu, a przez to zwiększenie poczucia faktycznej odpowiedzialności za realizację zadań ${ }^{15}$. Wskazana forma prezentacji części wydatkowej budżetu może być również wykorzystywana na potrzeby konsultacji społecznych, prac organów uchwałodawczych oraz mieszkańców danej jednostki terytorialnej.

W kontekście celu niniejszej pracy należy podkreślić, wskazywany przez K. Domańskiego i J. Szołno-Koguc, podział budżetu w układzie zadaniowym na dwie integralne części, zróżnicowane co do charakteru i zakresu: budżetu inwestycyj-

\footnotetext{
14 Ibidem, s. 9.

${ }^{15}$ K. Domański, J. Szołno-Koguc, Budżet zadaniowy. Wprowadzenie do metodologii, materiały szkoleniowe, s. 3, portal.wsiz.rzeszow.pl/plik.aspx?id=2755 (20.09.2010).
} 
nego oraz budżetu operacyjnego. Stąd ze względu na ww. części budżetu wyróżnia się odpowiednio:

- zadania inwestycyjne, których realizacja przekracza okres roku budżetowego, dzięki czemu przyczyniają się do powiększenia majątku gminy,

- zadania bieżące (operacyjne), które zamykają się w cyklach rocznych (w ramach roku budżetowego), choć mogą być grupowane w programy trwające dłużej niż rok $^{16}$.

Przedstawiony podział pozwala analizować ogólną kwotę wydatków budżetowych danej jednostki w ujęciu realizacji kolejnej części wieloletniego planu inwestycyjnego w danym roku, mając do dyspozycji budżet inwestycyjny przedstawiający wielkość środków finansowych przeznaczonych na realizację zadań inwestycyjnych i dający upoważnienie do wydawania tych środków. Podstawą dla budżetu inwestycyjnego jest wieloletni plan inwestycyjny, którego fragment dotyczący danego roku budżetowego, po odpowiednim rozwinięciu, jest włączany do budżetu gminy. Zadania inwestycyjne są to zadania, które służą powiększaniu majątku gminy, w tym majątku jednostek organizacyjnych gminy lub innych gminnych osób prawnych. Z kolei budżet operacyjny stanowi plan finansowy zadań bieżących, dotyczących operacyjnej aktywności gminy, codziennej działalności związanej ze świadczeniem usług na rzecz społeczności lokalnej. Zadania operacyjne mogą mieć charakter kontynuowany lub doraźny, zaś ich cykl realizacyjny i finansowy w każdym przypadku zamyka się w obrębie pojedynczego roku budżetowego.

\section{Rola budżetu w systemie zarządzania jednostką samorządu terytorialnego}

Procesy zarządzania rozwojem jednostki samorządu terytorialnego w obecnych warunkach wymagają aktywności i nastawienia na kreowanie jej przyszłości. Dlatego też niezbędna jest postawa lokalnych władz samorządowych uwzględniająca podejście strategiczne, którego efektem jest tworzenie warunków do zrównoważonego rozwoju gminy w dłuższym okresie. Proces ten w niniejszym opracowaniu scharakteryzowano na poziomie lokalnym, na podstawie uwarunkowań charakterystycznych dla gmin, gdzie działania podporządkowane misji gminy i wynikające z wyznaczonych celów o charakterze strategicznym mogą zapewnić optymalizację

16 Ibidem, s. 5-6. 
zaspokojenia potrzeb mieszkańców gminy oraz wykorzystania i wzrostu posiadanych zasobów, co jest nadrzędnym celem rozwoju lokalnego.

Informacje o stanie zasobów gminy, w tym zasobów komunalnych, zestawione wraz ze zbiorem rozpoznanych potrzeb społecznych danej wspólnoty powinny być przedmiotem działania procesów planowania strategicznego rozwoju gminy. Zgodnie z przesłankami planowania strategicznego $\mathrm{w}$ warunkach gospodarowania samorządu terytorialnego w Polsce należy podkreślić, że w przypadku gminy znaczna część celów przyjmowanych w planie strategicznym z reguły odnosi się do podejmowania działań o charakterze inwestycyjnym. Stąd też w opracowaniu wskazuje się, że efektem procesu planowania rozwoju gminy, w tym rozwoju mechanizmów świadczenia usług o charakterze użyteczności publicznej oraz procesu organizowania sposobów wykorzystywania dostępnych zasobów, jest polityka inwestycyjna gminy. Należy jednak zwrócić uwagę na konieczność zachowania spójności założeń i instrumentów polityki inwestycyjnej z kierunkami długookresowego rozwoju społeczno-gospodarczego gminy określonymi w strategii rozwoju danej gminy. Z założeń polityki inwestycyjnej powinny ponadto wynikać szczegółowe rozwiązania organizacyjne w zakresie planowania inwestycji w ujęciu rzeczowym, planowania źródeł i metod finansowania inwestycji, jak również w odniesieniu do możliwości wykorzystywania różnorodnych metod zarządzania i analizy ekonomicznej. W opracowaniu przyjęto zatem, że efektem polityki inwestycyjnej gminy są zindywidualizowane do warunków danej gminy instrumenty, których zastosowanie pozwala dokonać identyfikacji i formułowania zadań inwestycyjnych, wyodrębniania projektów inwestycyjnych i zestawiania portfeli projektów, dokonywania oceny wykonalności projektów, przeprowadzania ewaluacji ex ante w odniesieniu do portfeli projektów i poszczególnych i pojedynczych projektów oraz oceny i prognozowania wielkości środków inwestycyjnych dostępnych w przyszłości. W wyniku działań podejmowanych w ramach polityki inwestycyjnej gminy, przy wykorzystaniu wymienionych instrumentów, władze gminy powinny dysponować trzema typami zasobów wytworzonych w procesie planowania inwestycji, którymi są:

- wieloletni plan finansowy, obejmujący prognozę budżetu gminy w perspektywie długookresowej, uwzględniający wariantowe scenariusze kształtowania się dochodów i wydatków budżetowych, zdolność gminy do generowania nadwyżki operacyjnej budżetu, zdolność do zaciągania zobowiązań oraz identyfikację wraz z prognozą dostępności różnych źródeł i form finansowania inwestycji podejmowanych przez gminę,

- komunalne projekty inwestycyjne, zorganizowane $\mathrm{w}$ formie portfeli projektów lub funkcjonujące odrębnie, dla których wykonana została wstępna ocena 
wykonalności oraz ewaluacja pod kątem efektów i racjonalności z punktu widzenia celów rozwojowych gminy,

- instrumenty zarządzania projektami, stanowiące zestaw rozwiązań organizacyjnych dostosowanych do specyficznych uwarunkowań danej gminy i umożliwiających wdrażanie procedur identyfikacji i formułowania projektów inwestycyjnych, dokonywanie analizy ekonomicznej projektów, opracowywanie kryteriów i metod hierarchizacji i selekcji projektów, wdrażanie metod koordynowania realizacji wielu projektów inwestycyjnych, wdrażanie metod planowania zasobów i kierowania wykonaniem pojedynczych projektów oraz wdrażanie procedur monitoringu, kontroli i ewaluacji projektów na wszystkich etapach ich realizacji. Powyższe zasoby stanowią zbiór danych wejściowych do procesu optymalizacji, którego efektem powinno być dokonanie alokacji środków finansowych zaplanowanych w przyszłych budżetach gminy na projekty inwestycyjne wyselekcjonowane przy zastosowaniu przyjętych w danej gminie metod i kryteriów oceny oraz hierarchizacji projektów. W przedstawionym ujęciu alokacja oznacza zatem proces konstruowania rocznego budżetu inwestycyjnego. Budżet inwestycyjny definiowany jest jako plan rzeczowo-finansowy zawierający zestawienie wyselekcjonowanych projektów inwestycyjnych możliwych do zrealizowania w okresie roku budżetowego następującego po aktualnym na dany moment roku budżetowym wraz ze wskazaniem kwot środków finansowych oraz źródeł ich pozyskania. Także budżet zadaniowy może funkcjonować jako odrębny dokument w gminie, uzasadnione wydaje się jednak, aby w części dotyczącej inwestycji stanowił część opracowania planistycznego o dłuższym horyzoncie czasowym, np. wieloletniego planu inwestycyjnego. Z uwagi na uwarunkowania systemu finansów publicznych w Polsce można stwierdzić, że rola wieloletnich planów i programów inwestycyjnych w jednostkach sektora finansów publicznych jest w znacznym stopniu ograniczona. Stąd też jedynie część gmin w Polsce uznaje opracowywanie wieloletnich planów inwestycyjnych za działanie realnie wspomagające procesy planowania i realizacji inwestycji gminnych.

Z punktu widzenia celów polityki inwestycyjnej gminy należy ocenić wieloletni plan inwencyjny jako wartościowy instrument prognozowania potrzeb i możliwości inwestycyjnych gminy oraz formułowania i oceny zadań inwestycyjnych. Budżet inwestycyjny powinien więc być elementem podejścia strategicznego do problemów planowania inwestycji gminnych, jako dokument, w którym następuje uszczegółowienie działań z poziomu taktycznego zarządzania inwestycjami, pozwalające na przejście do poziomu operacyjnego, tj. w przypadku gminy obejmującego działania prowadzone $\mathrm{w}$ perspektywie roku budżetowego. Warto przy tym podkreślić, że w przypadku braku uchwalonego wieloletniego planu inwestycyjnego w gminie 
wzrasta znaczenie budżetu inwestycyjnego w układzie zadaniowym. Budżet inwestycyjny należy uznać za wynikający z ogólnych założeń polityki inwestycyjnej etap procesu tworzenia projektu budżetu gminy (także w układzie zadaniowym) na rok kolejny, w części dotyczącej wydatków majątkowych.

Etap zatwierdzenia budżetu inwestycyjnego, stanowiącego integralną część budżetu gminy, wiąże się z przeprowadzeniem procesów decyzyjnych, zgodnie z przepisami prawa dotyczącymi gospodarki finansowej gminy. Na tym etapie mogą być również zgłaszane uwagi i propozycje zmian w przedłożonym projekcie budżetu inwestycyjnego i w konsekwencji może występować konieczność dokonania korekt. Wprowadzane zmiany o charakterze rzeczowym i finansowym mogą powodować konieczność dodatkowej oceny głównie w zakresie zdolności do sfinansowania rocznego planu inwestycyjnego przy uwzględnieniu nowych uwarunkowań. W zależności od rodzaju i zakresu zmian dokonywanych w trakcie procesu decyzyjnego dodatkowe analizy mogą być również uzasadnione $\mathrm{w}$ odniesieniu do poszczególnych portfeli projektów lub pojedynczych projektów inwestycyjnych ujętych w rocznym planie inwestycyjnym. Na tym etapie powinny więc znaleźć zastosowanie instrumenty budżetowania zadaniowego, zarówno w odniesieniu do zadań bieżących, jak i przy konstruowaniu rocznego planu inwestycyjnego.

Uchwalony budżet gminy, w którego skład wchodzi budżet inwestycyjny, przekazywany jest odpowiednim komórkom organizacyjnym urzędu gminy do wykonania. Oznacza to możliwość uruchomienia środków budżetowych na realizację poszczególnych etapów projektów inwestycyjnych, zgodnie z ich indywidualnymi harmonogramami. W literaturze przedmiotu wskazuje się, że na omawianym etapie zarządzania projektami może występować najwyższy poziom ryzyka pojawienia się zakłóceń wykonania projektów i występowania istotnych odchyleń od założeń harmonogramów rzeczowo-finansowych. Dlatego też szczególnie ważnym działaniem jest wdrożenie systemu monitoringu przebiegu pojedynczych projektów oraz zestawionych portfeli inwestycyjnych. Ponadto informacje uzyskiwane dzięki wykorzystaniu narzędzi monitoringu stanowią istotny zasób danych empirycznych niezbędnych do prowadzenia kontroli oraz zastosowania odpowiednich narzędzi ewaluacji. Metodyka budżetowania w układzie zadaniowym zawiera zalecenia dotyczące szczegółowego planowania zasobów organizacyjnych i finansowych, jednocześnie też wskazując na konieczność opracowania wskaźników na potrzeby badania efektów prowadzoych działań.

$\mathrm{Na}$ tym etapie znajdą również zastosowanie instrumenty zarządzania projektami, odnoszące się do gospodarowania zasobami rzeczowymi i środkami finansowymi w środowisku wieloprojektowym. W większości przypadków podejmowanych projektów inwestycyjnych gmina występuje w roli inwestora generalnego, 
stąd też głównymi elementami procesu realizacji projektów jest nadzór nad terminowym wykonaniem poszczególnych etapów każdego z projektów oraz kontrola przepływu środków finansowych z budżetu gminy zgodnie z przyjętymi harmonogramami płatności. Należy jednak zwrócić uwagę na ryzyko pojawienia się różnego rodzaju konfliktów w zakresie wykorzystania zasobów gminy, wystąpienia nieprzewidzianych zdarzeń o charakterze losowym, opóźnień w stosunku do terminów ujętych w harmonogramach rzeczowo-finansowych $\mathrm{z}$ winy zewnętrznych wykonawców prac budowlanych czy też zmian w regulacjach prawnych skutkujących koniecznością wykonania dodatkowych analiz lub uzyskania dodatkowych decyzji administracyjnych.

Głównymi zagrożeniami w realizacji projektu, prowadzącymi do nieprzestrzegania założonego harmonogramu, kosztów i charakterystyki technicznej, może być więc niewłaściwa koordynacja prac projektowych i brak komunikacji między uczestnikami jego realizacji. Problem staje się jeszcze bardziej istotny w przypadku wielu projektów, tej samej wagi, w tym samym czasie, realizowanych dla tej samej gminy, ale koordynowanych przez innych kierowników prac, czyli inwestorów zastępczych. Ważnym elementem działań na rzecz rozwoju społeczno-gospodarczego gminy może więc okazać się uzupełnienie aktualnego schematu organizacyjnego urzędu gminy o jednostkę, wyposażoną w wiedzę i kompetencje umożliwiające podjęcie skutecznego zarządzania projektami inwestycyjnymi. Decyzja o utworzeniu specjalnego wydziału w urzędzie gminy czy też zaangażowaniu zewnętrznej instytucji do współpracy powinna być dostosowana do lokalnych uwarunkowań i podejmowana przez władze gminy.

W efekcie procesu realizacji inwestycji, wspomaganego wykorzystaniem instrumentów kontroli i ewaluacji projektów inwestycyjnych, zostają utworzone nowe elementy majątku trwałego. W konsekwencji wykorzystanie nowych lub zmodernizowanych składników infrastruktury przyczynia się do wzrostu jakościowego i ilościowego w zakresie usług o charakterze użyteczności publicznej. Jednocześnie można więc uznać, że uzyskana wartość dodana w wyniku zrealizowania projektu lub portfela projektów inwestycyjnych oznacza powiększenie zasobów materialnych i niematerialnych gminy. Zjawisko to zostało odwzorowane na schemacie zarządzania procesami rozwoju w gminie przedstawionym na rysunku 1.

Zgodnie z rysunkiem 1 demokracja lokalna określa powierzenie władzom samorządowym odpowiedzialności za dysponowanie zasobami gminy przez wspólnotę lokalną w celu wzrostu samych zasobów i podnoszenia efektywności wykorzystania dostępnych zasobów dla poprawy warunków życia i działalności gospodarczej na terenie danej gminy. Zmiany wartości księgowej, stanu technicznego, stopnia zaawansowania technologicznego oraz zgodności z wymaganymi normami 
Rysunek 1. Schemat zarządzania procesami rozwoju w gminie

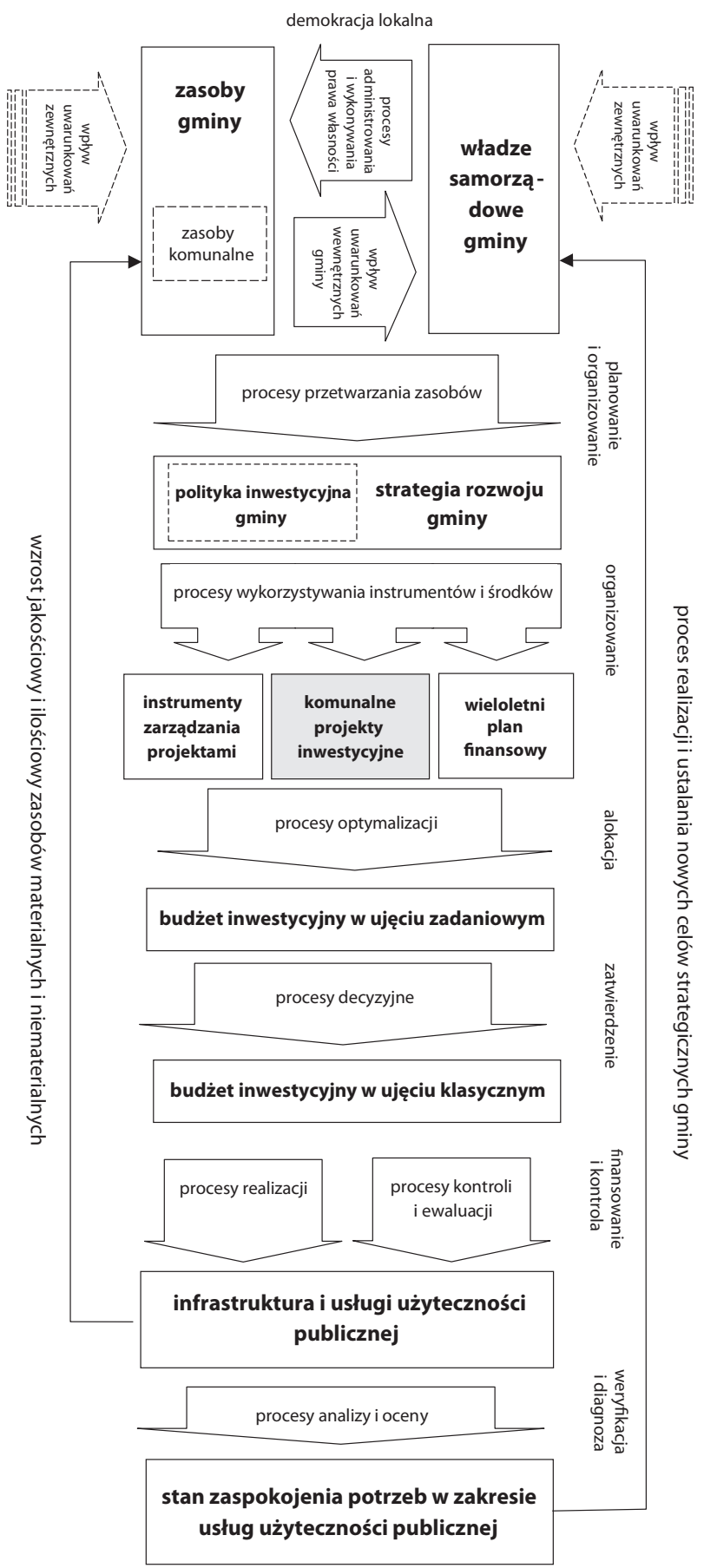

Źródło: opracowanie własne. 
i regulacjami prawnymi są to istotne cechy charakteryzujące składniki majątku trwałego gminy, które po zrealizowaniu nowego projektu lub portfela projektów inwestycyjnych powinny zostać poddane ponownej diagnozie i analizie porównawczej w stosunku do stanu zbadanego i opisanego na początkowym etapie analizowanego procesu zarządzania projektami inwestycyjnymi. Ocena tych zmian i odniesienie jej wyników do zgłaszanych potrzeb społecznych stanowi dla władz samorządowych istotną informację, która powinna być wykorzystana jako podstawa do weryfikacji przyjętych celów rozwojowych gminy i wprowadzenia ewentualnych aktualizacji do strategicznego planu rozwoju gminy.

$\mathrm{W}$ przedstawionym schemacie zarządzania procesami rozwoju w gminie istotne jest zatem zachowanie cykliczności planowania i realizacji komunalnych projektów inwestycyjnych. Zmianę uwarunkowań rozwojowych gminy oraz poziomu zaspokojenia potrzeb społecznych wynikającą z faktu wytworzenia nowych składników infrastruktury oraz zwiększenia zakresu świadczonych usług o charakterze użyteczności publicznej można uznać za bezpośredni czynnik zwiększający poziom rozwoju społeczno-gospodarczego danej gminy. Należy jednak przypomnieć, że potrzeby społeczne mają charakter nieograniczony, stąd też proces inwestycyjny w warunkach gminy uznawany jest za zjawisko ciągłe. Co więcej, zrealizowane projekty inwestycyjne i podwyższający się poziom ogólnego rozwoju gminy, w tym warunków bytowych ludności, mogą przyczyniać się do powstawania nowych, niezgłaszanych wcześniej potrzeb społecznych. Diagnoza zasobów po zrealizowaniu określonych projektów inwestycyjnych oraz rozpoznanie nowych potrzeb społecznych wyznacza zatem rozpoczęcie kolejnego cyklu zarządzania projektami inwestycyjnymi w gminie.

\section{Wykorzystanie budżetu zadaniowego w procesie zwiększania skuteczności i efektywności projektów inwestycyjnych w gminie}

Jak wskazano, początkowym etapem procesu planowania rozwoju gminy, ujmującego w sposób kompleksowy wszystkie sfery funkcjonowania gminy, powinna być identyfikacja zbiorowych potrzeb społecznych. Do prawidłowego określenia potrzeb społecznych, rozumianych jako prognoza przyszłego zakresu i form realizacji zadań jednostek samorządu terytorialnego szczebla lokalnego, zalecane jest podejście strategiczne, koncentrujące się na identyfikacji długookresowych kierunków rozwoju jednostki samorządu terytorialnego ujętych w misji oraz w sformułowanych celach strategicznych. 
Należy zauważyć, że dotychczasowe doświadczenia w zakresie procedur selekcji i koordynacji projektów inwestycyjnych oraz przedstawione problemy dotyczące zapewnienia długookresowego finansowania tychże projektów wskazują na potrzebę adaptacji nowych instrumentów zarządzania inwestycjami współfinansowanymi ze środków UE na różnych poziomach administracji publicznej. W zmieniających się warunkach funkcjonowania samorządu terytorialnego na szczeblu gminnym w Polsce niektóre instrumenty dotychczas stosowane w zarządzaniu finansami jednostek samorządu terytorialnego mogą nie spełniać w zadowalającym stopniu kryteriów skuteczności i efektywności na poziomie społecznych kosztów i korzyści.

W tym kontekście metody budżetowania zadaniowego wpisują się w potrzebę doskonalenia metod oceny poszczególnych projektów inwestycyjnych oraz rocznych i wieloletnich programów inwestycyjnych pod kątem ich skuteczności i efektywności. Służy temu niewątpliwie podkreślana w literaturze przedmiotu zbieżność pojęć zadania budżetowego oraz projektu inwestycyjnego. Przez zadanie budżetowe należy rozumieć zadanie wykonywane przez jednostki organizacyjne oraz osoby prawne i fizyczne, finansowane $z$ budżetu gminy. Jego celem jest osiągnięcie określonego długoterminowego rezultatu służącego mieszkańcom. Cel zadania budżetowego tworzy zakres merytoryczny, w jakim realizowane jest to zadanie. Cel powinien być wyrażony nie tylko jakościowo, ale także ilościowo, bardzo ważna jest bowiem jego mierzalność. W sposób szczegółowy określają powyższe cechy K. Domański i J. Szołno-Koguc, wymieniając przede wszystkim: jednoznacznie sprecyzowany cel, odniesienie do stanu istniejącego i potrzeb gminy, wskazanie szczegółowego zakresu zadania, określenie odpowiedzialności, skalkulowanie kosztów rzeczywistych realizacji zadania, specyfikację czynności niezbędnych do realizacji zadania rozplanowanych w czasie, określenie mierników skuteczności i efektywności oraz uwzględnienie przepływów finansowych ${ }^{17}$. Jak podkreśla ponadto M. Olczak, zadanie zyskuje cechy projektu, tj. poza celem, sposobem realizacji, odrębnym budżetem uzyskuje również harmonogram, co oznacza umieszczenie go w czasie zarówno działań, jak i ich skutków finansowych dla budżetu ${ }^{18}$.

W przypadku oceny projektów inwestycyjnych najczęściej stosowanymi miernikami są: wewnętrzna stopa zwrotu (IRR), aktualna wartość netto (NPV) projektu, a dodatkowo również ekonomiczna stopa zwrotu (ERR), która uwzględnia czynniki niepodlegające kwantyfikacji $\mathrm{w}$ formie monetarnej przy projektach użyteczności publicznej. W ujęciu oceny projektów inwestycyjnych w sektorze publicznym kwantyfikacja korzyści oraz kosztów o charakterze pozafinansowym może w bardzo

\footnotetext{
${ }_{17}$ K. Domański, J. Szołno-Koguc, op.cit., s. 4-5.

${ }_{18}$ M. Olczak, Rola budżetu zadaniowego $w$ zintegrowanym zarządzaniu gmina. W drodze do efektywności, materiały szkoleniowe, www.logincee.org/file/4216/library (07.09.2010).
} 
istotny sposób wpływać na ogólną ocenę danego przedsięwzięcia. W sytuacji takiej, charakterystycznej dla wielu typów projektów infrastrukturalnych, możliwa jest wycena ekonomiczna zarówno kosztów, jak i korzyści pojawiających się w wyniku podjętych działań przy użyciu specjalistycznych metod, np. analizy kosztów i korzyści (cost-benefit analysis). Ustalenie kosztów wynikających z realizacji projektu w zakresie infrastruktury, a w szczególności identyfikacja korzyści (co jest znacznie bardziej skomplikowanym zadaniem) wymaga zatem dysponowania zasobem informacji obrazujących przebieg funkcjonowania urządzeń infrastrukturalnych. Gromadzona w powyższy sposób wiedza pozwala identyfikować efekty w ujęciu ekonomicznym, nawet jeżeli $\mathrm{w}$ znacznie ograniczonym stopniu przejawiają się one bezpośrednio, a metody przybliżenia generowanych korzyści w ujęciu ilościowym są mało precyzyjne i trudne do weryfikacji jedynie na podstawie kryteriów finansowych.

W poszukiwaniu odpowiednich metod i instrumentów zarządzania programami i projektami realizowanymi w sektorze publicznym w coraz szerszym zakresie uwzględnia się i wymaga rozwoju analizy wskaźników służących badaniu efektów poszczególnych programów czy projektów inwestycyjnych. Niewątpliwie potrzebne będzie dalsze doskonalenie tworzonych już obecnie zasad gromadzenia i wykorzystywania informacji, które można uzyskać w wyniku analizy finansowej, a które mogą przyczyniać się do upowszechniania ilościowych metod badania i oceny efektywności wykorzystywania zasobów i środków finansowych na wszystkich poziomach administracji publicznej. Nie pozostaje to jednak w sprzeczności z potrzebą stosowania również wskaźników o charakterze rzeczowym. Zbiór wykorzystywanych wskaźników dla celów zarządzania w jednostce sektora publicznego ma być odpowiedni dla konkretnych zadań, typowych dla danego rodzaju działalności.

Zgodnie z charakterystyką prezentowaną przez B. Kuca za najważniejszą cechę wskaźników należy uznać mierzalność, która oznacza możliwość wyrażenia ich w kategoriach liczbowych, oraz zgodność i stałość, co pozwoli na uzyskiwanie ujednoliconego zakresu danych $\mathrm{w}$ poszczególnych cyklach pomiaru. W połączeniu z kolejną cechą, wskazującą, iż wskaźniki powinny być właściwe, można osiągnąć zdolność gromadzenia informacji zgodnych z założonymi celami danej jednostki organizacyjnej lub danego programu i tworzących podstawy informacyjne do podejmowania decyzji i dokonywania zmian organizacyjnych ${ }^{19}$.

Podstawową funkcją wskaźników jest umożliwienie prowadzenia regularnego badania wyników uzyskiwanych przez dany podmiot lub program na podstawie mierzalnych, obiektywnych parametrów dostarczających wiedzę potrzebną do oceny wyników. Wyniki analizy wskaźnikowej w kontekście przyjętych celów

19 B. Kuc, Kontrola i audyt w sektorze publicznym, PTM, Warszawa 2007, s. 182. 
i zaangażowanych zasobów mogą zatem stanowić istotną przesłankę do wyznaczenia obszaru i kierunku koniecznych działań w celu podniesienia skuteczności i efektywności funkcjonowania badanego podmiotu. Użyteczność odpowiednio skonstruowanych wskaźników przejawia się zatem w procesach monitoringu, kontroli oraz ewaluacji programów i projektów inwestycyjnych.

W literaturze przedmiotu wskazuje się na różne cele ewaluacji w poszczególnych fazach realizacji projektu czy programu. Podejście takie reprezentowane jest także w dokumentach wydawanych przez Komisję Europejską i mających charakter wytycznych dotyczących wykorzystania środków unijnych. Zgodnie z powyższym podejściem można wskazać ewaluację ex ante, ewaluację ongoing oraz ewaluację ex post $t^{20}$. Bezpośrednie odniesienie do tej klasyfikacji znajduje się również w przepisach prawa, określających zasady przeprowadzania oceny ex ante oraz oceny ex post w ramach poszczególnych celów polityki strukturalnej UE ${ }^{21}$.

Należy zatem zauważyć, że w szczególności ewaluacja pozwala uzyskać szeroki zestaw wskaźników społecznych i ekonomicznych, cechujący się znacznym stopniem unifikacji wynikającym ze stosowania jednolitych metod i technik wymaganych przez instytucje zarządzające środkami finansowymi na realizację projektów. Zakres uzyskanych wyników ewaluacji daje również podstawy do oceny uwzględniającej aspekty znajdujących się w obszarze zainteresowania możliwie wielu różnych instytucji i grup społecznych w zakresie programu lub projektu stanowiącego obiekt badania.

Analiza literatury przedmiotu oraz dokumentacji przygotowywanej w jednostkach administracji publicznej (np. Ministerstwa Rozwoju Regionalnego), obrazującej dotychczasowe doświadczenia w zakresie ewaluacji programów i projektów inwestycyjnych umożliwiających urzeczywistnianie celów o charakterze użyteczności publicznej, pozwala wskazać metody badawcze, których zastosowanie w procesach ewaluacji będzie znacząco upowszechniało się w perspektywie najbliższych lat. Przede wszystkim należy tu wyróżnić metodę określaną jako „matryca logiczna” (logical framework), polegającą na identyfikacji oczekiwanych efektów projektu na poziomie produktu, rezultatu i szerszego oddziaływania, a następnie na przyporządkowaniu każdemu z tych poziomów określonych wartości wskaźnika, które powinny zostać osiągnięte, oraz sformułowaniu założeń warunkujących uzyskanie zakładanego poziomu poszczególnych wskaźników. Efektem opracowania matrycy jest zatem zidentyfikowanie powiązań przyczynowo-skutkowych pomiędzy różnymi poziomami celów, określenie metod weryfikacji stopnia ich osiągnięcia oraz

${ }^{20}$ K. Ekiert, Ewaluacja w administracji publicznej. Funkcje, standardy, warunki stosowania, „Biuletyn RCSS" 2004, nr 17, s. 15.

${ }^{21}$ Rozporządzenie Rady (WE) nr 1083/2006, art. 48 pkt 2 oraz art. 49 pkt 3. 
sformułowanie założeń, które poza obszarem kontrolowanym przez projekt mogą wpływać na jego efekt końcowy.

$\mathrm{W}$ przypadku przedstawionych w opracowaniu instrumentów zarządzania, takich jak wieloletnie planowanie inwestycyjne i ewaluacja, w znacznym stopniu zwiększać się będzie zapotrzebowanie na szeroki zakres informacji ekonomicznych (nie tylko finansowych), bazujących najczęściej na określonym zestawie wskaźników o różnym stopniu szczegółowości. W perspektywie przyszłej realizacji projektów inwestycyjnych uzasadnione jest przypuszczenie, że analiza wskaźnikowa prowadzona na podstawie wyników badań i prognozy poszczególnych wielkości ekonomicznych, istotnych z punktu widzenia kształtowania się sytuacji finansowej danej jednostki, w coraz większym zakresie orientowana będzie na wspieranie procesu decyzyjnego pod względem kierunków alokacji i efektywności wydatkowania środków publicznych oraz opracowywania przyszłych planów finansowych zróżnicowanych jednostek sektora publicznego.

\section{Podsumowanie}

Politykę inwestycyjną samorządu terytorialnego można uznać za zagadnienie złożone, koncentruje bowiem ona zróżnicowane czynniki, obejmuje z reguły długi okres prognostyczny oraz realizację zróżnicowanych technicznie obiektów i urządzeń wchodzących w skład konstruowanych programów inwestycyjnych. Prawidłowe przygotowanie programów inwestycyjnych wymaga opracowania metodyki wyłaniania problemów infrastrukturalnych, które powinny być rozwiązane poprzez realizację inwestycji. W takim ujęciu realizacja inwestycji wymaga dokonania wyboru kierunku inwestowania, w szczególności podjęcia rozstrzygnięć dotyczących rodzaju inwestycji. W przypadku inwestycji podejmowanych przez gminy szczególną rolę w procesie optymalizacji nakładów inwestycyjnych może odgrywać budżetowanie w układzie zadaniowym, stanowiąc kolejny instrument zarządzania będący rodzajem łącznika pomiędzy planowaniem strategicznym (i realizacją strategicznych planów rozwoju określonych przez gminę) a zarządzaniem projektami inwestycyjnymi. Istnieje bowiem potrzeba wzmocnienia roli planowania zadań publicznych, i to nie tylko zadań inwestycyjnych, realizowanego w perspektywie przekraczającej rok budżetowy.

Przeprowadzona analiza pozwala wnioskować, że uwarunkowania organizacyjno-prawne polityki inwestycyjnej, w jakich funkcjonują jednostki samorządu terytorialnego w Polsce, charakteryzują się nadal znacznym poziomem niepewności. W zakresie podejmowania działań o dłuższej perspektywie realizacji przeprowadzone 
zmiany głównych aktów prawnych regulujących gospodarkę budżetową trudno oceniać jako dostatecznie zaawansowane. Należy ocenić, że podążają one we właściwym kierunku, jednakże nadal w głównej mierze opierają się na rocznej perspektywie planowania budżetowego.

Metody budżetowania zadaniowego wpisują się w potrzebę doskonalenia metod oceny poszczególnych projektów inwestycyjnych oraz rocznych i wieloletnich programów inwestycyjnych pod kątem ich skuteczności i efektywności. Służy temu niewątpliwie podkreślana w literaturze przedmiotu zbieżność pojęć zadania budżetowego oraz projektu inwestycyjnego. Ważne jest również rozszerzanie stosowania analiz opartych na wskaźnikach finansowych i rzeczowych. Stosowanie tych wskaźników jest jednym z podstawowych założeń metodycznych budżetowania w układzie zadaniowym.

Proponowana często w literaturze przedmiotu metodyka oceny projektów inwestycyjnych opiera się na wykorzystaniu uproszczonej metody analizy wartości. Oznacza to, że analizę poszczególnych zadań inwestycyjnych, prowadzącą do ustalenia kolejności ich realizacji, powinna poprzedzać decyzja zatwierdzająca kryteria oceny tych zadań oraz nadająca punktowe wagi wybranych kryteriów. Jako efekt tej fazy planowania powstaje hierarchiczna lista projektów inwestycyjnych rekomendowanych do zatwierdzenia w najbliższym okresie obejmowanym przez plan. W nawiązaniu do analizowanych w opracowaniu problemów oceny i hierarchizacji inwestycji publicznych główne argumenty uzasadniające korzyści zastosowania budżetowania zadaniowego w świetle przeprowadzonej analizy to przede wszystkim uzyskanie narzędzia o charakterze systemowym, koncentrującego wykorzystanie posiadanych zasobów na osiąganiu priorytetowych celów podmiotu. Włączenie metod budżetowania zadaniowego w ogólny system zarządzania w jednostce samorządu terytorialnego wzmacnia lub nawet zastępuje wieloletni plan inwestycyjny (w przypadku jego braku). W odniesieniu do zadań budżetowych realizowanych przez daną jednostkę samorządu terytorialnego ujęcie zadaniowe wymusza identyfikację działań priorytetowych wraz z kwantyfikacją oczekiwanych wyników tych działań.

Należy jeszcze raz podkreślić, że powyższe podejście umożliwia badanie racjonalności wydatkowania środków publicznych na wszystkie typy zadań, w tym również o charakterze usług publicznych czy usług typowo administracyjnych. W największym stopniu korzyści z zastosowania metod budżetowania zadaniowego dotyczą procesów inwestycyjnych, w których budżet zadaniowy wprowadza zasadę analizy kosztów i korzyści realizowanych projektów. Jak wskazują wyniki przeprowadzonej analizy, poprzez zastosowanie licznych instrumentów analizy efektywności zaczerpniętych z nauk ekonomicznych i społecznych budżetowanie zadaniowe stanowi czynnik stymulujący zastosowanie mierników ilościowych oraz jakościowych do oceny zadań publicznych w zakresie ich racjonalności, skuteczności i efektywności. 


\section{Planning and evaluation of investment projects of the self-government units with the use of task budgeting methods}

Organizational and legal conditions influencing the investment policy of Polish self-government units can be judged as still uncertain. The need for strengthening the role of long term planning in public finance remains one of the most vital and current problems, which is especially important in accordance to the investment projects in the public sector.

The research indicated that effectiveness of the investment projects executed by the self-government units can be significantly improved by using elements of task budgeting methodology. Task budgeting can be therefore considered as an instrument of management which helps to link strategic planning with the investment project management. Widening the scope of implementation of task budgeting should lead to the improvement of methods of theeconomic evaluation of investment projects as well as annual and long-term programs. The important factor is that the terms: 'budgetary task' and 'investment project' are highly similar. That similarity can stimulate developing analytical methods which are based on financial and material indicators.

Main conclusions of the conducted research are that the most important advantages of implementing the task budgeting methods derive from their role as strong analytic tool helping to manage any types of the unit's resources and concentrating on achieving strategic goals. The conducted analysis also proved that with the use of wide scope of analytical tools, the task budgeting methodology strongly stimulates expansion of implementing quantitative and qualitative indicators in evaluation of the public investment projects.

\section{La planification et l'évaluation des projets d'investissement des entités de l'autonomie locale en utilisant la méthode de la budgétisation par objectifs}

L’analyse effectuée par l'auteur révèle que les conditions organisationnelles et juridiques de la politique d'investissement, dans lesquelles les entités de l'autonomie locale fonctionnent en Pologne, sont encore caractérisées par un niveau élevé d'incertitude. Il est nécessaire de renforcer le rôle de la planification à long terme des finances publiques, ce qui est particulièrement important du point de vue des projets d'investissement. 
L'étude indique que l'efficacité des projets d'investissement réalisés par des entités de l'autonomie locale peut être considérablement améliorée en utilisant des éléments de la méthode de budgétisation par objectifs. Cette budgétisation peut donc être considérée comme un instrument de gestion qui contribue à lier la planification stratégique avec la gestion de projets d'investissement. Élargir le champ d'application de la budgétisation par objectifs devrait conduire à améliorer les méthodes d'évaluation économique des projets d'investissement ainsi que des programmes annuels et des programmes à long terme. Le facteur important est que les termes: «objectif budgétaire» et «projet d'investissement» sont très similaires, ce qui peut stimuler le développement des méthodes analytiques basées sur des indicateurs financiers et matériels.

Les avantages les plus importants de la mise en œuvre des méthodes de budgétisation par objectifs découlent de leur rôle comme un instrument analytique, aidant à gérer tous les types de ressources de l'entité et se concentrant sur la réalisation des objectifs stratégiques. L'analyse effectuée prouve également que grâce aux outils analytiques, la méthode de budgétisation par objectifs stimule fortement l'expansion de la mise en ouvre des indicateurs quantitatifs et qualitatifs en matière d'évaluation des projets d'investissement publics. 